Vol. 06, No. 02; 2021

ISSN: $2456-8643$

\title{
PROFITABILITY AND CONSTRAINTS TO ONION (Allium cepa L.) PRODUCTION IN KEBBI STATE, NIGERIA
}

\author{
Umar Magaji, Yahaya Kakaand and Abdullahi Auwal Gindi \\ Department of Agricultural Economics and Extension, Faculty of Agriculture, Kebbi State University of Science and \\ Technology, PMB 1144, Aliero, Kebbi State, Nigeria. \\ https://doi.org/10.35410/IJAEB.2021.5616
}

\begin{abstract}
Onion (Allium cepa L.) is one of the major cash crops grown mostly in northern Nigeria, nevertheless with perpetual scarcity at off season due to its perishability as producers lacked adequate storability thus, sells at low price to avoid spoilage at hand. The study seeks to evaluate profitability of onion production and its constraints in Kebbi State, Nigeria. Seven Local Government Areas were purposively selected from the state. Four stage sampling procedures were used in selecting 210 onion producers using structured questionnaire. The data collected was analyzed using SPSS software and gross income analysis. The result of the study revealed that mean output of onion in bagsha- 1 was 71.58 bags with an average price of 15597.05 but incurred loss of $18.71 \%$ ha- 1 . The estimated gross margin, net farm income, gross ratio, operating ratio and return on capital investment provides an estimated values of $700,388.33 \mathrm{ha}-1$, 956.99ha-1, 0.40, 0.37 and 1.68 respectively. Production and marketing constraints identified were; high cost of inputs, pest and disease attack, poor storage facilities and poor pricing. In conclusion, onion production is a profitable enterprise. The study recommends for government/nongovernmental sustainable financial, technical and educational interventions for the enhancement of onion production in the study area.
\end{abstract}

Keywords: Onion, Producers, Profitability, Cost, Returns, Constraints.

\section{INTRODUCTION}

According to [1], almost half of the world population lives in urban areas. The urbanization trend is expected to continue and even to accelerates, especially in Africa and Asia. This phenomenon has given birth to an increased demand for fresh fruits and vegetables which need to be met by new production areas combined with more intensified crop management in order to raise the productivity per unit of land and water. Onion is one of the most commonly consumed vegetable crops in the world with China being the number one producer of onions while Japan and India are the second highest producers of green onions and dry onions respectively[2]. [3], statistical report on highest onion producing countries, Nigeria with 621,000 tons annual production ranked 24th in the world and 4th in Africa behind Egypt, Algeria and Morocco. In Nigeria, onion is grown mostly in Kano, Kaduna, Jigawa, Sokoto, Plateau, Bauchi and Kebbi States. Onion producers in northern Nigeria are trying their best to produce and supply the bulk of onion to address local demand but yet has not completely satisfied local consumption as there is still occasional impact of scarcity due to its unending demand. This indicates that the market is 
Vol. 06, No. 02; 2021

ISSN: $2456-8643$

large enough to accommodate investors. Kebbi State is one of the largest onions producing state in northern Nigeria and is also home to some of the biggest onion traders as in Aliero, and Yauri Local Government areas. However, production of vegetables like onion is also prone to pest and disease attack with a short shelf life after harvest due to its high perish ability, whereas the local producers lacked modern storage facilities and techniques to preserve this highly perishable crop leading to the hurried sales of harvested products at ridiculously low prices to avoid spoilage and reduce loss suffered by the farmers. This leads to scarcity of the product, once the harvest season is over. There is, therefore, a need to study the profitability of onion production in Kebbi State and understand the various constraints at grassroots level militating against its production. This may benefit the existing and potential onion producers as well as policy makers, researchers and other stakeholders in the activities of onion. Though there are many literatures on onion production carried out in different states in the country like; economic analysis, resource use efficiency, disease perception, risk attitude[4, 6]. However, there is also the need to update the research and findings on the crop so as to sustain growth and development of the economy and providing empirical evidence on onion producers' cost and returns in the business which is very scares or not available in the study area.

\section{MATERIALS AND METHODS:}

\subsection{Study Area}

The study was conducted in Kebbi State located in the north-western part of Nigeria between latitudes $10^{\circ} 8^{\prime} \mathrm{Nand} 13^{0} 15^{\prime} \mathrm{N}$ and longitudes $3^{\circ} 30^{\prime} \mathrm{E}$ and $6^{\circ} 02^{\prime} \mathrm{E}$. The State is bordered by Sokoto and Zamfara States to the east, Niger State to the south, Benin Republic to the west and Niger republic to the north. Kebbi State occupies an area of about 37, 699 square kilometers out of which $36.46 \%$ is made up of farmland [7]. The State has an estimated population of about 3.24 million, out of which $49.9 \%$ are males, while $50.1 \%$ are females [8]. Kebbi State has tropical weather conditions with three seasons: rainy, dry and hot. The annual rainfall is variable and declining, being $600 \mathrm{~mm}$ to $850 \mathrm{~mm}$ and on average $650 \mathrm{~mm}$. The monthly temperature in the region ranges from $25^{\circ} \mathrm{C}$ to $45^{\circ} \mathrm{C}$. The state possessed two important agricultural lands namely: dryland (arid-prolonged dryness) and fadama (floodplains-significant alluvial clay particles). These two lands remained the key source of income to millions of people in the state [9]. Agriculture is the most important economic activity, with riverine floodplains producing crops like groundnuts, cotton, rice, millet, sorghum and vegetables such as tomato, onions etc. Most of the land in the state is used for grazing cattle, goat and sheep. The major ethnic groups in the State include Fulani, Hausa, Dakarkari and Kambari.

\subsection{Sampling Procedure}

Multistage and simple random sampling procedures were adopted to select the respondents from the study area.At the initial stage Kebbi State Ministry of Agriculture and Natural Resources was contacted for a comprehensive list of onion producing Local Government Areas in the state. At the second stage, seven local government areas were purposively selected out of 13 local government areas that are into onion production in the state based on their relative involvement and high onion production. The local governments selected were; Aliero, Augie, Birnin Kebbi, Gwandu, Maiyama, Shanga and Yauri local government areas. In the third stage two dominant 
villages were purposively selected from each of the seven local government areas based on the large number of onion producers in the area making a total of 14 villages. The fourth stage, in each of the 14 villages, a list of onion farmers was compiled with the help of the Village Headin charge of his respective area of jurisdiction. Simple random sampling method was employed in the selection of 15 respondents in each of the villages given a total sample size of 210 onion producers used for the study.

\subsection{Data Collection}

In addressing this research topic, both primary data and secondary information were used for the study.The primary data was generated via field survey by the use of structured questionnaire, administered to the sampled respondents in the study area with the assistance of trained enumerators under the supervision of the researcher. Secondary information includes journals, government reports, text books and unpublished materials.

\subsection{Analytical Tools}

Descriptive statistics was used to analyze constraints to onion production, whilegross margin analysis was adopted to ascertain the profitability of onion production.

\subsubsection{Descriptive Statistics}

Descriptive statistics was used in form of frequency count, percentage, mean, maximum, minimum, range to summarize constraints faced by the respondents as well as profit and loss range values.

\subsubsection{Gross Margin Analysis}

Gross Margin (GM) can be defined as the difference between the Gross Farm Income (GFI) and the Total Variable Cost (TVC). It is a useful planning tool in situations where fixed capital is negligible portion of the farming enterprises in the case of small scale subsistence agriculture [10]. Gross margin analysis is a method of calculating profitability of small scale cropping enterprises [11]. The gross margin as used in this analysis is explicitly expressed as below:

$\mathrm{GM}=\mathrm{GFI}-\mathrm{TVC}$

Where GM=Gross Margin, GFI=Gross Farm Income, TVC=Total Variable Cost

Gross Ratio(GR): This is a profitability ratio that measures the overall success of the farm. The rule of thumb is that the lower the ratio, the higher the return per naira. This is expressed as:

$\mathrm{GR}=\frac{T F E}{G I}$

Where:GR=Gross Revenue, TFE=Total Farm Expenses, GI= Gross Income.

Operating Ratio (OR): This is directly related to the farm variable input usage. It implies that the lower the ratio, the higher the profitability of the farm enterprise.

$\mathrm{OR}=\frac{T O C}{G I}(3)$

Where:OR=Operation ratio, TOC=Total Operation Cost, GI=Gross Income.

Return on Investment (RI): This is express as gross margin divided by total variable cost

$\mathrm{RI}=\frac{G M}{T V C}$

Where: RI=Return on capital Investment, GM=Gross Margin, TVC=Total Variable Cost. 
Vol. 06, No. 02; 2021

ISSN: $2456-8643$

\section{RESULTSAND DISCUSSION}

\subsection{Costs and Returns on Onion Production}

Costsand returns component for onion production is presented in Table 3.1. The table shows per hectare costs of onion produced in the study area, which reveals the total cost of production to be $\$ 448479.85 \mathrm{ha}^{-1}$. Fixed cost value constituted the least expenditure of 32431.34 incurred from depreciation of farm implements and rent which revealed the low level of investment on fixed assets as indicated by the lowest percentage $(7.76 \%)$ of the total cost of production by the onion producers in the study area. The cost value of fertilizer was higher than other variable inputs in this production as one of the most important input in onion production which made up of 25.64\% ( $107,112.72$ ) followed by cost of seed 13.92\% ( $\$ 58154.91$ ) expended per hectare. This could be due to high cost of inputs procured for production. The study further reveals that N112211.48 was expended on labour which constituted $26.86 \%$ of the total cost of production. The research study clearly showed that labour cost, fertilizer and seed constituted the largest proportion of the total cost of onion production. Thus, the findings indicated that variable cost accounted for $92.23 \%$ of the total cost. This finding is in agreement with that of[12] who studied profitability and constraints to dry season vegetables production in Sokoto State, Nigeria and found out that variable cost accounted for $92.19 \%$ of the production cost. The mean output of onion in bagsha ${ }^{-1}$ was 71.58 bags with an average price of 15597 . The estimated gross margin, net farm income, gross ratio, operating ratio and return on capital investment provides an estimated values of $\$ 700,388.33 \mathrm{ha}^{-1}$ 667, 956.99ha $\mathrm{ha}^{-1}, 0.40,0.37$ and $\$ 1.68$ respectively. The implication of the results is that for every one naira invested in onion production one naira sixty eight kobo ( $1.68 \mathrm{k}$ ) was realized. In general, the cost and return analysis indicated that onion production in the study area was lucrative. The results also concord with the findings of [13] who studied profitability and technical efficiency in onion production in Sokoto State, Nigeria revealed that the return on a naira invested was N3.58 while gross and operating ratios were 0.21 and 0.25 respectively indicating profitability of onion production.

Table 3.1: Estimated Costs and Returns Structure for Onion Production and Marketing

\begin{tabular}{|lcr|}
\hline Cost items and revenue & Cost (A/Ha) & Percentage \\
\hline Material Inputs & & \\
Seed (kg) & 58154.91 & 13.92 \\
Fertilizer (kg) & 107112.72 & 25.64 \\
Manure (kg) & 34485.23 & 8.26 \\
Agrochemicals (liters) & 19409.58 & 4.65 \\
Petrol (liters) & 35307.47 & 8.45 \\
Engine oil (liters) & 13428.39 & 3.21 \\
\hline
\end{tabular}


Vol. 06, No. 02; 2021

ISSN: $2456-8643$

\begin{tabular}{|lrr|}
\hline Maintenance & 5194.39 & 1.24 \\
Total Material Input Cost & 273092.70 & 65.37 \\
Labour Inputs & & \\
Land Preparation & 31473.18 & 7.53 \\
Planting & 20864.10 & 4.99 \\
Replacement & 3556.96 & 0.85 \\
Fertilizer application & 2571.13 & 0.62 \\
Manure application & 4463.23 & 1.07 \\
Spraying & 4724.11 & 1.13 \\
Weeding & 21654.61 & 5.18 \\
Harvesting & 22813.75 & 5.46 \\
Cutting & 90.42 & 0.02 \\
Total Labour Input Cost & 112211.48 & 26.86 \\
Marketing charges & 30744.33 & \\
Total Variable Cost & 416048.51 & 92.23 \\
FixedCost & & \\
Depreciation of machine/equipment & 11163.96 \\
Rent & $700,388.33$ & \\
Total Fixed Cost & & \\
Total Cost & 11691.73 & \\
Revenue Component & 20739.61 & \\
Average output & 32431.34 & \\
Selling Price & 448479.85 & \\
Gross Farm Income & & \\
Gross Margin & & \\
\hline
\end{tabular}


Net Farm Income

Gross ratio

Operating ratio

Return on Capital Investment
$667,956.99$

0.40

0.37

\#1.68

Source: Field survey data, 2020

\subsection{Individual Onion Producers' Output, Revenue and Loss Indices}

Onion production has been reported to be a profitable business; however, it is also associated with losses which could be either before or after harvest. Pursuant to the earlier discussion on cost and returns presented, the indices of each onion producer were further estimated in terms of output range, net revenue and losses incurred as presented in Table 3.2. The results in the table shows that majority of the onion producers (32.4\%) produced between 21 and 40 bags of onion in one production cycle and also many producers (47.6\%) incurred losses between 1 and 20 bags of onion, while highest number of the producers (21.4\%)pulled a stream of revenue from $\$ 401$, $000: 00 \mathrm{~K}$ to $600,000: 00 \mathrm{~K}$ and $18.7 \%$ (16.47bags) was the percentage loss per hectare as experienced by the producers in the study area.The report on proportion of losses of onion as contained in this report, somehow concords with the findings of [14] which confirmed as covered in their study work that $25 \%$ of vegetable is spoiled along the marketing channel resulting to huge loss of income, also[5] found out that loss incurred as a result of pest and disease attack accounts for $90 \%$ loss in output of onion in their study area. Therefore, there is the dire need for timely intervention by governments and other stakeholders for better policies that could be able to reduce the loss to an acceptable threshold.

Table 3.2: Distribution of Physical Output, Revenue and Loss of Individual Onion Producers in the Study Area

\begin{tabular}{|lrr|}
\hline Variable Range & Frequency & Percentage \\
\hline Output (Bag) & 18 & 8.6 \\
Up to 20 & 68 & 32.4 \\
$21-40$ & 64 & 30.5 \\
$41-60$ & 28 & 13.3 \\
$61-80$ & 6 & 2.9 \\
$81-100$ & 9 & 4.2 \\
$101-120$ & 4 & 1.9 \\
$121-140$ & & 9 \\
\hline
\end{tabular}


Vol. 06, No. 02; 2021

ISSN: $2456-8643$

\begin{tabular}{|c|c|c|}
\hline $141-160$ & 5 & 2.4 \\
\hline $161-180$ & 3 & 1.4 \\
\hline$>180$ & 5 & 2.4 \\
\hline \multicolumn{3}{|l|}{ Loss in output (bag) } \\
\hline $00-00$ & 66 & 31.4 \\
\hline $01-20$ & 100 & 47.6 \\
\hline $21-40$ & 33 & 15.7 \\
\hline $41-60$ & 4 & 1.9 \\
\hline $61-80$ & 4 & 1.9 \\
\hline$>80$ & 3 & 1.5 \\
\hline \multicolumn{3}{|l|}{ Revenue (“000”) } \\
\hline $50-200$ & 31 & 14.7 \\
\hline $210-400$ & 36 & 17.1 \\
\hline $401-600$ & 45 & 21.4 \\
\hline $601-800$ & 30 & 14.3 \\
\hline 801-1.0 million & 28 & 13.3 \\
\hline$>1.0$ million & 40 & 19.0 \\
\hline Average outputha ${ }^{-1} 71.58$ bags & 210 & 81.3 \\
\hline Average lossha ${ }^{-1} 16.47$ bags & 210 & 18.7 \\
\hline
\end{tabular}

Source: Field survey data, 2020

\subsection{Onion Production and Marketing Constraints}

Constraints to onion production are given in Table 3.3. Five most prioritized production problems confirmed by the respondents were; expensiveness of input (84.8\%), inadequate knowledge about the inputs (50.5\%), pest and disease attack (46.2\%), poor quality of the inputs (27.6\%) and inadequate or poor storage facilities (25.7\%). These findings imply the need for identified sustainable intervention by government support policies to easy access to inputs and extension services to address the cumulative effect of these production problems. Somehow, these problems are similar in other studies in Nigeria by [4 and 6]. Some other studies in Bangladesh and Ethiopia identified similar problems to be limiting factor to onion production as 
revealed by [15 and 17] respectively. The findings of this study have further identified in order of priority the most glaring marketing problems as confirmed by the onion producers to include but not limited to; poor pricing (41.90\%), pest and diseases (36.7\%), poor storage (29.5\%), trader activity (29\%). This also agrees with findings of [15, 17, and 18]. The consequences of this finding are that lack of good market supporting factors may dampen onion producers' vigor to expand production and the guarantee of its availability may be doubted even at higher prices.

Table3.3: Producers' Constraints to Onion Production and Marketing

\begin{tabular}{|llll|}
\hline Constraints & Frequency (*n=210) & *Percentage & Rank \\
\hline Production constraints & 178 & & \\
Expensive/high cost of inputs & 106 & 84.80 & 1 \\
Inadequate knowledge of inputs & 97 & 50.50 & 2 \\
Pest and diseases attack & 58 & 46.20 & 3 \\
Poor quality of inputs & 54 & 27.60 & 4 \\
Inadequate storage facilities & 50 & 25.70 & 5 \\
Shortage of land & 46 & 23.80 & 6 \\
Non-availability of labour & 46 & 21.90 & 7 \\
Shortage of input (i.e. fertilizer, seed) & 21.90 & 7 \\
Inadequate water supply & 45 & 21.40 & 8 \\
Inadequate credit facilities & 38 & 18.10 & 9 \\
Lack of extension services & 38 & 18.10 & 9 \\
Marketing constraints & & & \\
Poor pricing & 88 & 41.90 & 1 \\
Pest/Diseases & 77 & 36.70 & 2 \\
Poor storage & 62 & 29.50 & 3 \\
Traders' activities & 61 & 29.00 & 4 \\
Transportation cost & 60 & 28.60 & 5 \\
Perishability & 54 & 25.70 & 6 \\
\hline
\end{tabular}


Lack of government assistance

Bad roads
54

44
25.70

21.00
6

7

Source: Field survey data, 2020

*Multiple responses were consider

\section{CONCLUSION AND RECOMMENDATIONS}

In view of the findings of this research work it is concluded that investment in business of onion productionis profitable and capable of reducing poverty, wealth creation and job security. Flowing from the research findings it is recommended that onion producers should be linked with financial institutions like Bank of Agriculture (BOA), Nigeria Incentive-Base Risk Sharing System for Agricultural Lending (NISAL) and other commercial and Micro-Finance Banks for ease of access to soft loans to facilitate acquisition of new farm technologies/implements for planting, harvesting and sorting.Onion producers need to be trained on new storage techniques, while government should sponsor for a scientifically build onion storage structures within major onion producing areas to address problems of its seasonality and perishability.

\section{REFERENCES}

[1] Mike N, Martins H. Growing Vegetables for Home and Market: Rural Infrastructure and Agro-Industries Division, FAO Diversification Booklet,Rome.2009; 11:1-102

[2] Sence Agric. Onion [internet].2017 March [cited 2019 November 21]. 1-10p. Available from https://www.agriculturenigeria.com/production/cropproduction/horticulture/onion

[3] Food and Agricultural Organization (FAO). Food and Agriculture Organization Statistical Databases (FAOSTAT)[internet]. Rome, Italy; 2015 [cited 2019 December 5]. Availablefrom www.fao.org $>$ nigeria $>$ nigeria-at-a.

[4] Abdul Z, Abba A, Chigozi AS,Mohammed AB. Resource use Efficiency in Onion Production among Participating and Non-participating Farmers in Hadejia Valley Irrigation Project, Jigawa State, Nigeria. Journal of Agriculture and Veterinary Science. 2015;8:69-73.

[5] DaudaWP, Alao SEL, Zarafi AB,Alabi O.Farmers Perception of "Danzazzalau":Disease Affecting Onions in Kebbi State, Northwestern Nigeria. Tanzania Journal of Agricultural Science.2016;15(2):93-100.

[6] Opeyemi EA,Tohib, OO. Effect of Socioeconomic Characteristics and Income Status on Onion Farmers Risk Attitude in Sokoto State, Nigeria. Agricultural Tropical ET Subtropical.2017;50(3):141-146.

[7] Kebbi State Government. About Kebbi.[internet].2018 [cited 2019 November 24]. Available from www.kebbistate.org.ng.

[8] National Population Commission (NPC).Population Figure. Federal Republic of Nigeria, Abuja. 2006 [cited2019November 28]. Available from http://www.npc.ng. gov.

[9] Usman S, Noma SS,Kudiri AM. Dynamic Surface Components of Land and Vegetation Types in Kebbi State Nigeria. Eurasian Journal of Soil Science. 2016; 5(2):113-120. 
[10] Olukosi JO, Isitor SU,Ode MO. Introduction to Agricultural Marketing and Prices: Principles and Applications. Living Books Series, Gu Publications, FCT- Abuja; 2007. 37-48.

[11] Olukosi, JO,ErhaborPO.Introduction to Agricultural Marketing and Prices: Principles and Applications. Agitab Publishers Ltd, Zaria;1998.

[12] Tsoho BA,Salau SA. Profitability and Constraints to Dry Season Vegetable Production under Fadama in Sudan Savannah Ecological Zone of Sokoto State, Nigeria.Journal of Development and Agricultural Economics.2012; 4(7):214-222.

[13] Ojo MA, Mohammed US, Adeniji B,Ojo, AO. Profitability and Technical Efficiency in Irrigated Onion Production under Middle Rima Valley Irrigation Project in Goronyo, Sokoto State, Nigeria.Continental Journal of Agricultural Science.2009;3: 7-14.

[14] Benzabih E,Hadera G.Constraints and Opportunities of Horticulture Production and Marketing in Eastern Ethiopia. Dry Lands Coordination Group. Report No. 46. Grensen 9b. Norway. 2007.

[15] Hailegiorgis D.Value Chain Analysis of Onion in Dugba District, Oromia Region, Ethiopia. Archives of Current Research International. 2017:7(4):1-16

[16] Agidew A.Review on Onion Value Chain Analysis in Ethiopia. Nutrition and Food Science International Journal.2018:6(5): 1-5.

[17] Addisu H, Lemma Z,Kindie G. Value Chain Analysis of Onion: The Case of Ejere District, West Shoa Zone, Oromia National Regional State of Ethiopia. African Journal of Agricultural Economics and Rural Development, 2017; 5(1):512-524.

[18] Bultossa T. Survey and Analysis of Onion Marketing in Toke-Kutaye District, West Shewa zone, Oromia National Regional State, Ethiopia.Trends in Agricultural Economics.2017:10: 18-25. 